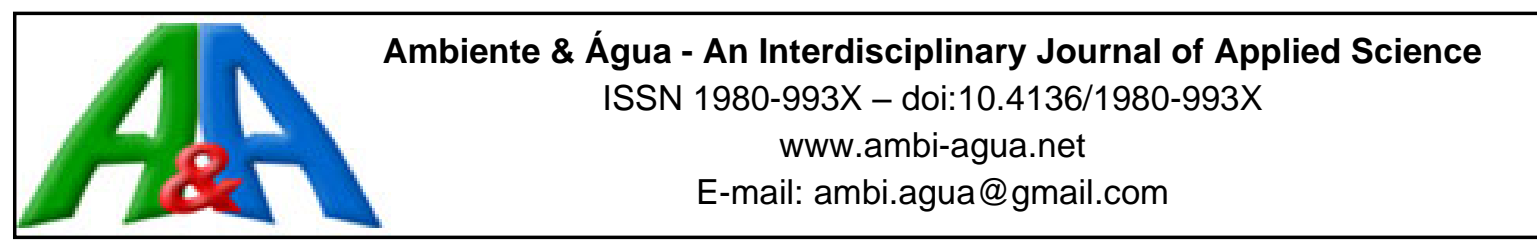

\title{
Brazilian offshore oil exploration areas: an overview of hydrocarbon pollution
}

\author{
ARTICLES doi:10.4136/ambi-agua.2569
}

Received: 03 May 2020; Accepted: 07 Jul. 2020

\author{
Daniel Constantino Zacharias*iD; Adalgiza Fornaro \\ Departamento de Ciências Atmosféricas. Instituto de Astronomia, Geofísica e Ciências Atmosféricas (IAG). \\ Universidade de São Paulo (USP), Rua do Matão, n 1226, CEP: 05508-090, Butantã, SP, Brazil. \\ E-mail: adalgiza.fornaro@iag.usp.br \\ *Corresponding author. E-mail: danizach@gmail.com
}

\begin{abstract}
The basins of Campos and Santos, the most important offshore oil reserves in Brazil, hold potential for being the largest offshore oil exploration fields in the next decades, mainly due to the oil located in the pre-salt layer. This region presents real conditions for the occurrence of intense atmospheric events added to the high velocity of the meanders of the Brazilian current. However, the increasing risk of accidents and damage in the region has been the subject of concern and discussion. The risks in the basins of Campos (2011) and Santos (2012) may not exhibit the the same potential for disastrous events as do those in the oil fields of Alaska and of the Gulf of Mexico, but accidents in these areas are not unlikely, as already evidenced by previous accidents under similar operating conditions (e.g. Chevron Platform accident in Campos Basin, RJ, Brazil, 2011). This paper highlights discussion of the multidisciplinary and substantial environmental features in oil exploration fields along the Brazilian coast based on Semi-Systematic Review methodology. The aspects evaluated cover not only geological traits, oceanic and meteorological circulation, but also current oil production, the most significant oil spill accidents recorded up to 2019 and the discussion about some current levels of seawater contamination.
\end{abstract}

Keywords: Campos basin, offshore contamination, oil spill, pre-salt layer, Santos basin.

\section{Área de exploração de petróleo na costa brasileira: uma visão geral poluição por hidrocarbonetos}

\section{RESUMO}

As bacias de Campos e Santos são as reservas de petróleo offshore mais importantes do Brasil e possuem potencial para serem os maiores campo de exploração de petróleo offshore nas próximas décadas, principalmente devido ao óleo localizado na camada do pré-sal. Esta região apresenta condições reais para a ocorrência de eventos atmosféricos intensos, somados à alta velocidade dos meandros da corrente marítimas brasileira. No entanto, o risco crescente de acidentes e danos na região tem sido objeto de preocupações e discussões. Os riscos nas bacias de Campos (2011) e Santos (2012) podem não apresentar potencial para eventos desastrosos como nos campos de petróleo no Alasca e no Golfo do México, mas os acidentes nessas áreas não são improváveis, como já evidenciados por acidentes anteriores em condições operacionais semelhantes (por exemplo, acidente na plataforma da Chevron na Bacia de 
Campos, em 2011). Este artigo mostra a discussão sobre as características multidisciplinares e ambientais substanciais em campos de exploração de petróleo ao longo da costa brasileira, com base na metodologia de Revisão Semi-Sistemática. Os aspectos avaliados abrangem não apenas características geológicas, circulações oceânicas e meteorológicas, mas também se destacando a atual produção de petróleo, os acidentes de derramamento de óleo mais significativos registrados até 2019 e a discussão sobre alguns níveis atuais de contaminação da água do mar.

Palavras-chave: bacia de Campos, bacia de Santos, contaminação nas águas costeiras, derramamento de óleo, pré-sal.

\section{INTRODUCTION}

Brazil holds the $15^{\text {th }}$ largest oil reserve worldwide and the $2^{\text {nd }}$ in Latin America with 12.2 billion barrels in offshore fields and 0.6 billion barrels in onshore fields. The Campos and Santos oceanic sedimentary basins hold $94 \%$ of all Brazilian oil (ANP, 2018). In 2017, Pre-Salt ultra-deep fields produced 1.3 million barrels per year of oil and 18.2 billion $\mathrm{m}^{3}$ per year of natural gas, which means almost half of all Brazilian oil and $45 \%$ of its natural gas oil (ANP, 2018).

Santos Basin, the largest sedimentary offshore basin in Brazil, spans from Cabo Frio city (Rio de Janeiro state - RJ) to Florianópolis city (Santa Catarina state - SC), covering an area of more than $350,000 \mathrm{~km}^{2}$, where the deepest oil platforms are installed on the Brazilian coast (Petrobras, 2018). Most wells are located between the parallels $21^{\circ} \mathrm{S}$ and $23^{\circ} \mathrm{S}$, covering an area of approximately $100,000 \mathrm{~km}^{2}$. The basin carries out intense oil-related activities, such as drilling, transportation and ship-to-ship transfers, which cause high risk of contamination for the ocean biome (Wagener et al., 2012).

Research related to oil exploration has become increasingly complex, and the multidisciplinary approach to existing knowledge plays an essential role for new advances in scientific development in the area. This task requires precision as a priority, in addition to the breadth of the topics covered, by synthesizing previous and current knowledge by systematic methods of literature review, leading to important research questions which are not found in single studies (Snyder, 2019).

The present paper explores the discussion regarding multidisciplinary and substantial environmental features in oil exploration fields along the Brazilian coast based on SemiSystematic Review methodology. The aspects evaluated cover not only geological traits, oceanic and meteorological circulation, but also highlight current oil production, the most significant oil spill accidents recorded up to 2019 and the discussion about some current levels of seawater contamination. The objective is to show and discuss the current conditions of offshore oil exploration at Campos and Santos Basins, summarizing some useful environmental aspects to support further studies such as oil-spill modeling and environmental impact assessment and providing integrated and critical information for modelers and policy makers in order to discuss levels of water contamination. This integrated knowledge was evaluated considering its influence on environmental impact assessments and oil-spill computational simulations.

\section{MATERIALS AND METHODS}

There are a number of existing guidelines for literature reviews, with all types being appropriate to a specific aim. These approaches can be qualitative, quantitative, or mixed depending on the phase of the review. In specific goals and circumstances, some of these strategies can be useful to answer a particular research question, based on literature review methods such as systematic, semi-systematic and integrative (Snyder, 2019). 
The methodology chosen for this article was the semi-systematic, because the purpose of semi-systematic review is to present an overview of the research area and sometimes to track the development of the research or theme over time (Snyder, 2019).

In the semi-systematic approach, the search strategy may or not be systematic with quantitative or qualitative analysis and evaluation, contributing to the state-of-the-art knowledge, themes in literature, historical overviews, research agendas or theoretical models (Snyder, 2019). As the studied topic is very broad, the search universe was expanded (quantitative articles, research articles, books and other published texts), which is more usual in the integrated methodology (Snyder, 2019).

The semi-systematic approach, also called narrative review, is designed for topics that have been conceptualized differently and studied within diverse disciplines that hinder a full systematic review process. In general, the semi-systematic approach seeks to identify and understand all potentially relevant research traditions that have implications for the studied topic, instead of measuring effect size to provide understanding of complex areas (Snyder, 2019).

The present work was systematized as follows:

- Purpose: Environment overview research on Campos and Santos Basins; and the development of oil exploration and spills in recent decades.

- Research questions: What are some environmental conditions that influence Campos and Santos Basins?

What is the condition of oil production in these basins, including spills?

Have current knowledge and legal instruments (environmental impact assessment EIA) been sufficient to prevent contamination of sea water?

- Search strategy: Not systematic.

- Sample Characteristics: Quantitative articles, research articles, books and other published texts.

- Analysis and Evaluation: Qualitative.

- Expected Contribution: State of the art knowledge; historical overview; interdisciplinary discussion; discussion of current water quality policy.

The present work shows the semi-systematic methodology to analyze aspects usually present in oil spill modeling and EIA: study area background, geology, oceanic circulation, atmospheric circulation, current status of oil use/exploration, water quality and residual impacts summary (Glasson and Therivel, 2012).

\section{RESULTS AND DISCUSSION}

\subsection{Geological Aspects of Southeast Coast of Brazil}

The Southeast coast of Brazil comprises the states of Espírito Santo (ES), Rio de Janeiro (RJ), São Paulo (SP), Paraná (PR), Santa Catarina (SC) and Rio Grande do Sul (RS), as well as the sedimentary basins of Espírito Santo, Campos, Santos and Pelotas, where the main offshore oil fields and pre-salt reserves are located (Figure 1). 


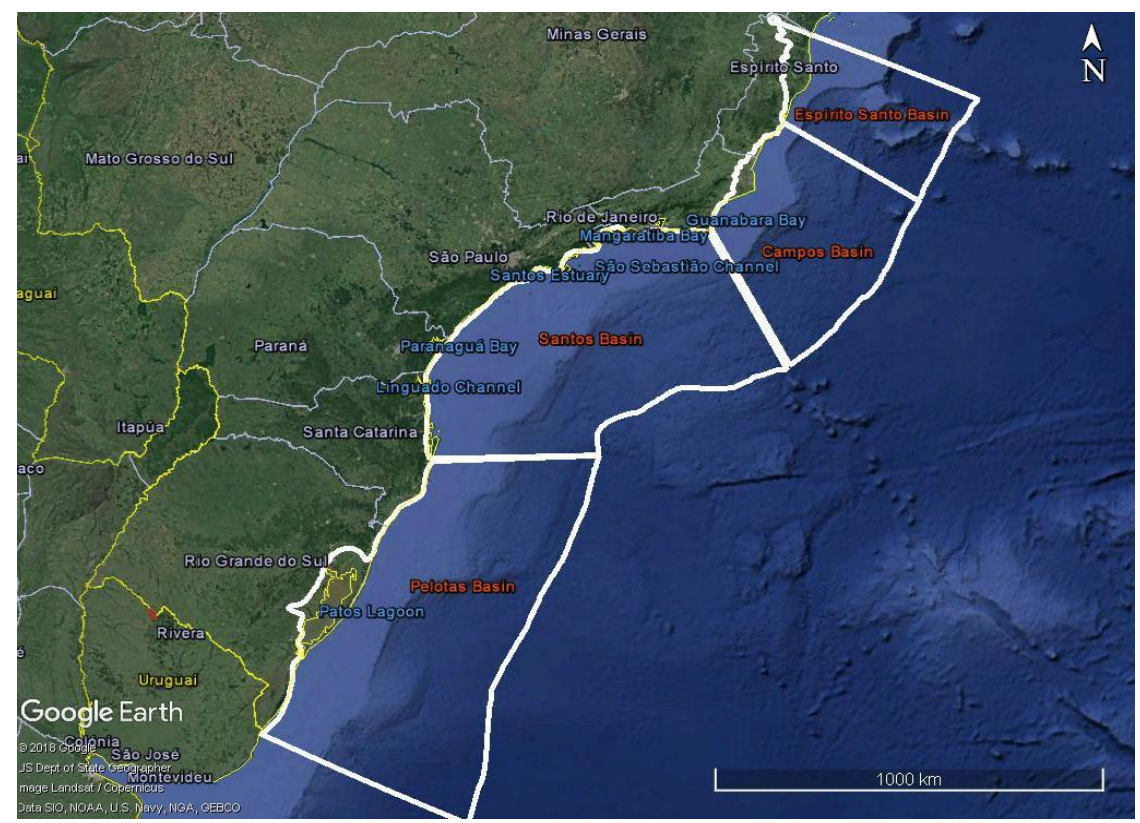

Figure 1. The oceanic sedimentary basins of the Brazilian South and Southeast coasts. Source: Google Earth and Domingos (2011).

The Santos Sedimentary Basin covers $352,000 \mathrm{~km}^{2}$ and is located in the South Atlantic Ocean, between $23^{\circ} \mathrm{S}$ and $28^{\circ} \mathrm{S}$ (Figure 1). It exhibits a bathymetric dimension that reaches 3,000 meters of depth and a sedimentary thickness of more than 10,000 meters, and represents one of the largest sedimentary basins in Brazil with one of the biggest continental margin depressions (Papaterra, 2010).

The Pelotas sedimentary basin, with an area of $210,000 \mathrm{~km}^{2}$ is located between $28^{\circ} \mathrm{S}$ and $34^{\circ} \mathrm{S}$ on the coast of Santa Catarina and Rio Grande do Sul states (Figure 1). The Campos Sedimentary Basin, between $21^{\circ} \mathrm{S}$ and $23^{\circ} \mathrm{S}$, covering a total area of $115,000 \mathrm{~km}^{2}$, is the smallest of the three basins in the studied area, stretching along the coasts of Rio de Janeiro and Espírito Santo states, being limited by the Santos Basin in the South near Cabo Frio (CPRM, 2018).

The Santos Basin can be divided, according to its geology, in two distinct parts separated by a slope. The shallow continental shelf of Santos, no more than $200 \mathrm{~m}$ deep, is delimited by the coast and a canyon structure. The extension of the basin is the São Paulo Plateau, which is bordered by the slope in its portion close to the coast, oriented towards the interior of the ocean, and reaching depths of 4,000 $\mathrm{m}$ (Pellizzon, 2005).

The main oil reservoirs in Brazil are located in the sedimentary basins of Santos and Campos, which were originally interconnected and resulted from the initiation of the rifting process that caused its formation due to deep geological faults. The onset of Santos and Campos Basins dates back to approximately 130 million years ago, in the Cretaceous period, and they are characterized as rift (lake), post-rift (gulf) and drift (ocean) stages (Riccomini et al., 2012).

The rift stage was initiated with volcanism (Figure 2), where the movement of geological faults led to basin formation due to the deposition of lake sediments, such as basalt, sandstone, quartz, feldspar, silt and shale rich in organic matter, which means a potential oil generator (Mello et al., 1995).

The second stage, the post-rift, was initiated by the sea entrance in the south, controlled by basaltic rock reliefs, becoming an elongated and narrow gulf shape. The persistency of weathering caused by floor sinking, water salinity, hot temperature and high evaporation rates, raised an extensive 2,500 m thick layer of salt, which consists mostly of halite and anhydrite (Papaterra, 2010). 


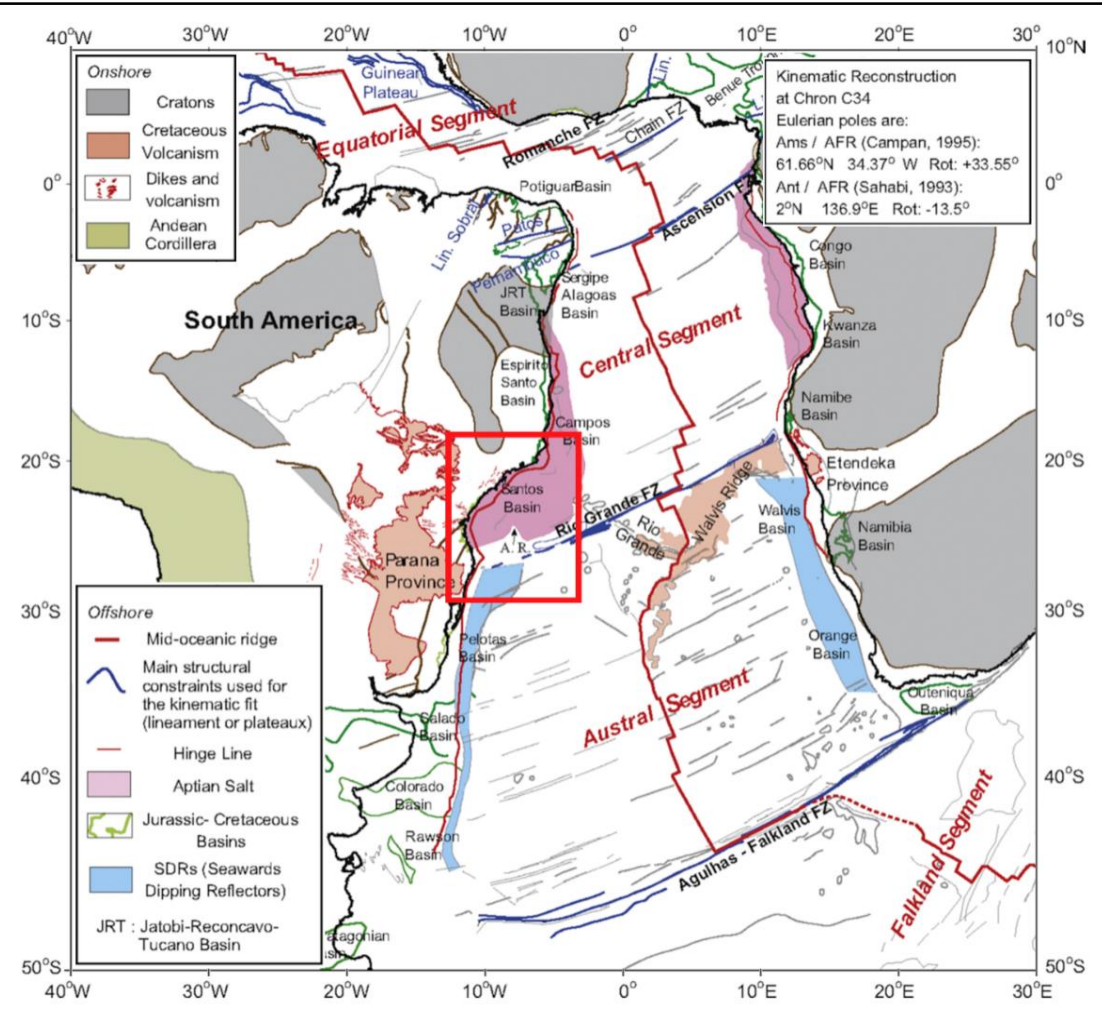

Figure 2. The tectonic-structural and bathymetric features of the South Atlantic Ocean at Chron-34 using the Eulerian pole data. The red square highlights the location of the studied area. Source: Adapted from Alves et al. (2017).

Those areas, accumulated by volcanic basalt rocks with their characteristic patterns, such as high porosity and permeability fractures, can be considered excellent reservoirs. The pre-salt deposit functions as a reservoir of carbonate rocks, which form an exploratory area of oil accumulation with varied topography of high and low reliefs. The salt and sediment pile over the salt layer exerts the sealant function, burying the previous layer and completing the pre-salt oil system in the region (Riccomini et al., 2012).

The Santos Basin (Figure 2) was initially part of an extensive region of continental rifting, separating South America and Africa. The latest Jurassic and Early Cretaceous rifting, Late Cretaceous salt tectonics and continental breakup were triggered in the Austral segment during the Late Jurassic period. Later, they were propagated northwards into the equatorial segment during multiple phases of tectonism related to the Andean Orogeny (Alves et al., 2017).

\subsection{Oceanic Circulation}

The oceanic area evaluated in this study is characterized mainly by the Brazil Current (BC) (Figure 3), a western boundary current, which is associated with the South Atlantic Subtropical Gyre (Peterson and Stramma, 1991). The Brazil Current originates near the Brazilian Northeastern Coast, at the bifurcation of the Equatorial South Current, flowing from $9^{\circ} \mathrm{S}$ to $38^{\circ} \mathrm{S}$ and carrying warm subtropical water (Silveira et al., 1994). It reaches the Subtropical Convergence between $33^{\circ} \mathrm{S}$ and $38^{\circ} \mathrm{S}$, converging with the Malvinas Current, Brazil-Malvinas Confluence (BMC), and moves away from the coast. The BC, being a western boundary current characterized by intense, narrow and well-defined flow along the coast (Figure 3), is relatively weak when compared to the North Atlantic current (Silveira et al., 2000). The Brazil Current region, formed by the stacking of water masses characteristic of the South Atlantic, has its first three kilometers of depth originated from tropical waters. Its depth is followed by South Atlantic and Antarctic waters, and finally, by Upper Circumpolar and North Atlantic deepest waters (Silveira et al., 2000). 


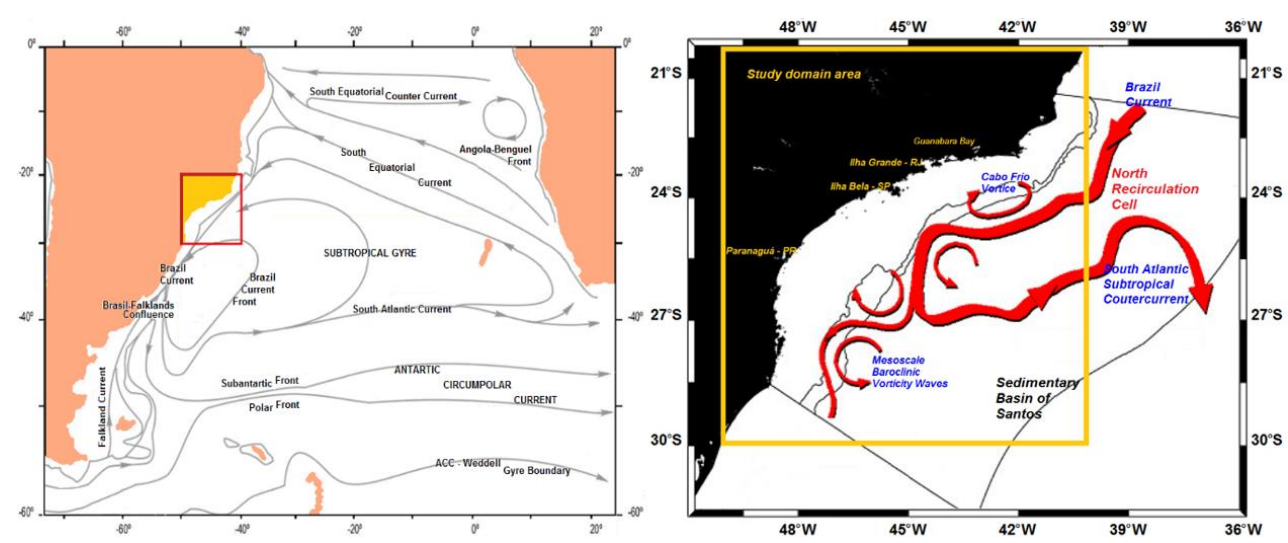

Figure 3. The Brazil Current (BC) and the boundaries of the studied area are highlighted by the surface currents (gray lines) and the surface recirculation systems (red arrows). Source: Adapted from Peterson and Stramma (1991); Mattos (2006); Soares (2014).

Ocean data estimate that the $\mathrm{BC}$ becomes deeper and more intense towards the South, varying from $200 \mathrm{~m}$ at Cabo Frio surroundings, $22^{\circ} \mathrm{S}$, to $670 \mathrm{~m}$ near Cabo Santa Marta, $28^{\circ} \mathrm{S}$ (Silveira et al., 2000). The transient phenomena of the BC are also very relevant factors for its dynamics (Figure 3), with intense mesoscale activity, meanders and vortices, mainly between Vitoria $\left(20^{\circ} \mathrm{S}\right)$ and Cabo Santa Marta $\left(28^{\circ} \mathrm{S}\right)$. The BC begins to reach deeper areas near Cabo Frio, stretching and acquiring cyclonic vorticity, triggering a wave of vorticity along Santos Basin (Silveira, 2007). It is important to highlight that, in Cabo Frio, this process is caused by the abrupt change in the orientation of the coastline and by the bathymetric gradient (Soares, 2014).

The existence of recirculation cells associated with the western boundary currents could explain the volume variations of the sea water transport along their route (Figure 3), which causes the subdivision of the South Atlantic Subtropical in two circulation cells, centered between $23^{\circ} \mathrm{S}$ and $30^{\circ} \mathrm{S}$, with anticyclonic movement close to $27^{\circ} \mathrm{S}$. The first part of the BC stream moves from the western contour $\left(44^{\circ} \mathrm{W}\right)$ to the east $\left(37^{\circ} \mathrm{W}\right)$, characterizing the South Atlantic Subtropical Countercurrent. The second moves towards the southwest, characterizing the Southern branch of the Northern Recirculation Cell (Mattos, 2006). The movement of a coldwater plume flowing northwards was observed in the Brazilian southeastern continental shelf (Figure 3). The resurgence in the Arraial do Cabo region-RJ is also included in the domain of the study, originating from the divergence generated by the presence of the coast and the rotational wind field in open ocean (Soares, 2014). Many studies about relative vorticity indicated that vortices could occur in the Brazilian Current throughout the year, especially in the Cabo Frio Vortex (Figure 3) (Soares, 2014).

\subsection{Atmospheric Circulation}

On the southeastern coast of Brazil, atmospheric circulation is characterized, on a synoptic scale, mainly by the movement of transient systems such as: cyclonic vortices, frontal systems, and the South Atlantic Convergence Zone (SACZ) (Barros et al., 2000; Carvalho et al., 2004; Siqueira and Machado, 2004; Taschetto and Wainer, 2008).

The South Atlantic Convergence Zone (SACZ) is a band of cloud cover extending from the Atlantic Ocean in the South and Southeast regions of Brazil, passing through areas of oil exploration, and entering the continent. This type of formation remains stationary for more than three days, resulting in long rainy periods (Carvalho et al., 2004; Ambrizzi and Ferraz, 2015).

The climatic conditions in this region present transitional characteristics between the tropics and subtropics, and the local atmosphere ends up being marked by cycles of tropical and extratropical systems. The dynamic of the atmospheric circulation is characterized by the polar 
front passages (Figure 4), alternating with the influence of the South Atlantic Subtropical High (SASH) on the region (Rocha et al., 2019).
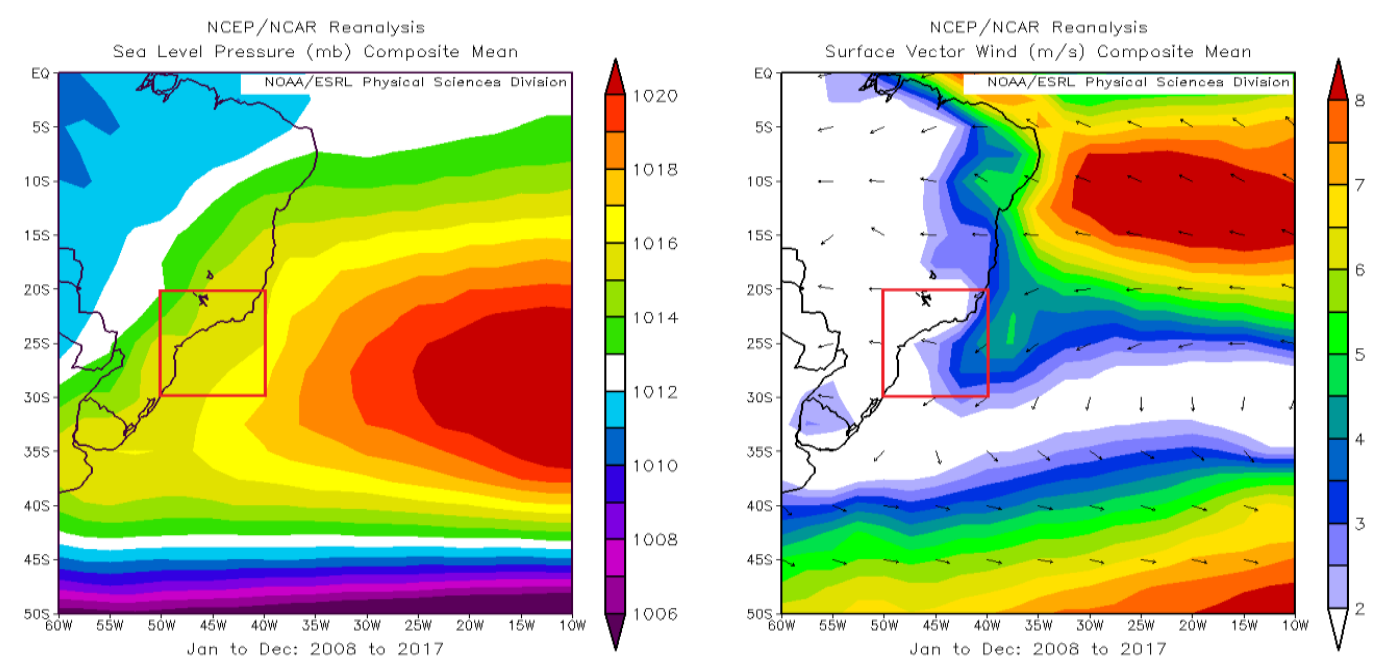

Figure 4. Reduced pressure at sea level and surface wind climatology (10-year mean) from the NCEP re-analyzes (National Centers for Environmental Prediction) data, highlighting the limits of the studied domain (red square). Source: NOAA (2020).

The subtropical highs, relatively warm semi-permanent systems compared to high migratory pressures, are high-pressure systems located around $30^{\circ} \mathrm{S}$, with their center between $20^{\circ} \mathrm{S}$ and $40^{\circ} \mathrm{S}$ over the oceans in the Southern hemisphere, these semi-permanent anticyclones are associated with the subsidence area of Hadley cells circulation (Rocha et al., 2019). The South Atlantic Subtropical High (SASH) moves over the South Atlantic Ocean according to the seasons (Gilliland and Klein, 2018), covering a larger area during winter and becoming more restricted and more defined during summer (Rocha et al., 2019).

In the basic climatological conditions, it is expected that the main direction of both wind (Figure 4) and stream (Figure 3) carry the spilled oil to the southern coast of Brazil. The wind regime on the oceanic portion of the domain originates from E/NE (Figure 4), following the Brazil Current (Figure 3). In oil spills under the influence of high pressure conditions, the winds are predominantly weak and less capable of determining the trajectory of the slick than the vortices and meanders of Brazil and Subtropical South Atlantic Currents (Figure 3). Although the basic climatological condition is influenced by SASH on the domain, a slight wind rotation contour is also observed clockwise within the domain (Figure 4), resulting from the synoptic scale flow perturbations in large-scale flow, mainly cyclonic and frontal systems.

Cyclones are synoptic scale systems characterized by low surface atmospheric pressure, clockwise rotation in the South Hemisphere (SH), presenting the ability to change wind flow. They are also a significant mechanism of energy transport and humidity between latitudes (Dutra, 2012). On the SE coast of Brazil, the development and passage of cyclones can directly affect weather conditions, which results in heavy rains, strong winds and maritime agitation, negatively affecting the port and shipping activities (Dutra, 2012). Subtropical cyclones, like tropical and extratropical, are hybrid systems presenting warm and cold cores at low and upper levels, respectively. They occur mostly over the sea, generating intense winds near the surface, which seriously affects human activities and ecosystems (Rocha et al., 2019).

Regardless of the cyclone types that may occur, the area for oil exploration is located in one of the three regions of the South American cyclogenesis and very close to the other two (Reboita et al., 2010a; 2010b). In a very simplified analysis, cyclogenesis usually occurs at least once a month within, or very close to, the domain area (Figure 5). 


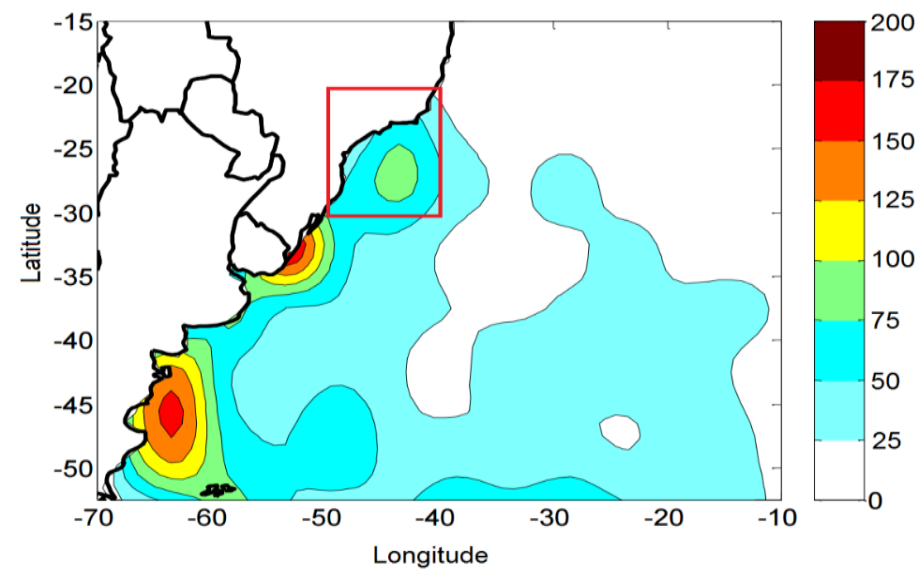

Figure 5. Number of cyclogeneses detected yearly with initial vorticity below $1.5 \times 10^{-5} \mathrm{~s}^{-1}$ and lifetime of over 24 hours, considering data from the NCEP (National Centers for Environmental Prediction) re-analysis, from 1979 to 1999. Red square highlights the Santos Basin central area. Source: Adapted from Reboita et al. (2010b).

The climatological condition in the grid region shows a predominance of winds from the E/NE quadrants (Figure 4), with an orientation similar to Brazil Current (Figure 3). In contrast to this situation, there are transient (migratory) cyclonic systems (Figure 5) altering the winds from this region to NW origin (pre-frontal position) and S/SW (post-frontal position).

Wind data from the Santos buoy (Argos ID: 69150|WMO ID: 31374, Figure 6), obtained from GOOS-BRASIL (Prediction and Research Moored Array in the Tropical Atlantic PIRATA), showed that in the Santos Basin, the wind flows towards the coast at a $30 \%$ frequency, causing more risks to environment. Intense winds $\left(>10 \mathrm{~ms}^{-1}\right)$ flow $18 \%$ of the time, increasing risks to maritime activities.
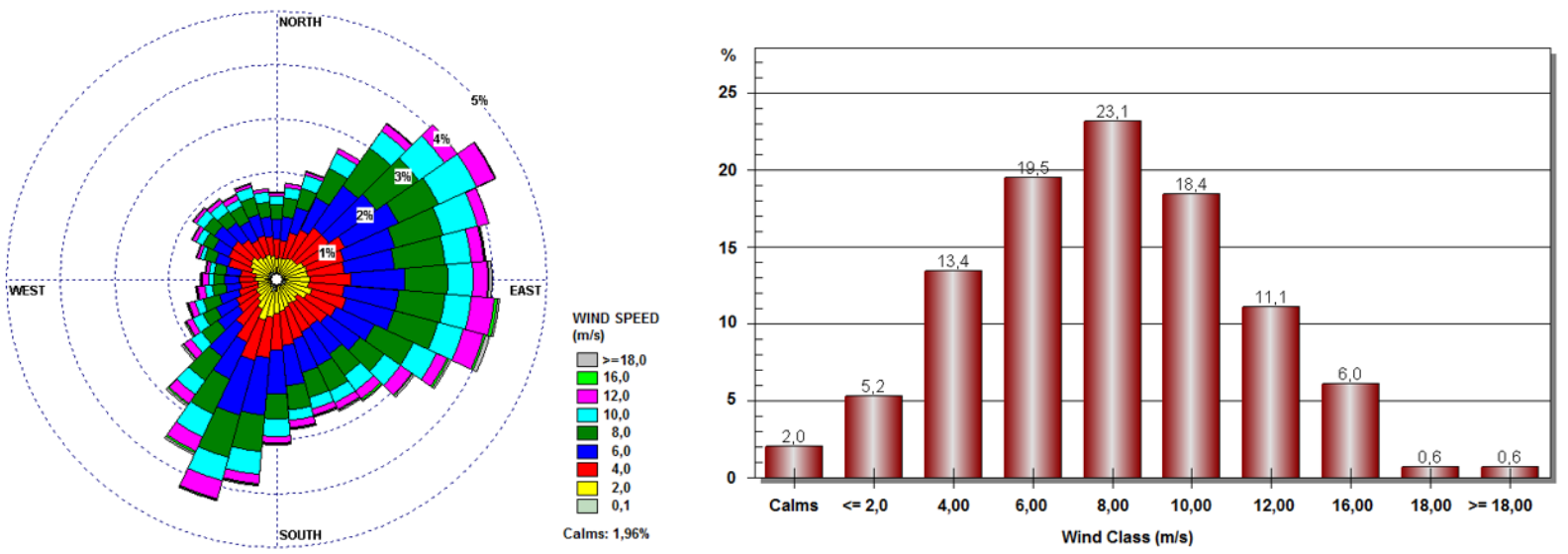

Figure 6. Wind directional histogram at 10 meters, measured with the Santos Buoy (Argos ID: 69150 WMO ID: 31374). Source: GOOS-Brasil (2020).

\subsection{Oil Offshore Exploration}

Brazilian offshore oil exploration started before the current environmental legislation, protection rules and federal agency.

Environmental impact assessment (EIA) started in early 1960s in United States, followed by Europe in middle of 1980s; however, it reached international status only in 1992, with the Rio de Janeiro Declaration on Environment and Development, in its Principle 17 (Devuyst, 2000; Roos et al., 2020), to which Brazil was a signatory. 
The Federal Constitution of Brazil (Brasil, 1988) required the execution of an EIA in any project with potential for environmental damage and created the IBAMA (Brazilian Institute of the Environment and Natural Resources); since then, environmental impact assessment has been used in the licensing processes for oil extraction activities in Brazilian waters (in new and previous fields) to prevent contamination and pollution.

The Campos Basin exploration started in the Garoupa field in 1976, but the Enchova field was the first to reach 10,000 barrels per day of oil production, in 1977 (Santos et al., 2017). After a 40-year exploration, although the fields (Figure 7) are still currently mature considering the peak of oil and gas production, decommissioning and changes of platforms and extraction points are expected in the next decades (Coelho, 2010). Oil production in Brazil grew 8\% in 2015 compared to 2014 due to the increase of pre-salt wells extraction (Oliveira, 2016). The average production in 2015, 2016 and 2017 totaled almost 13 billion barrels per year (ANP, 2018).

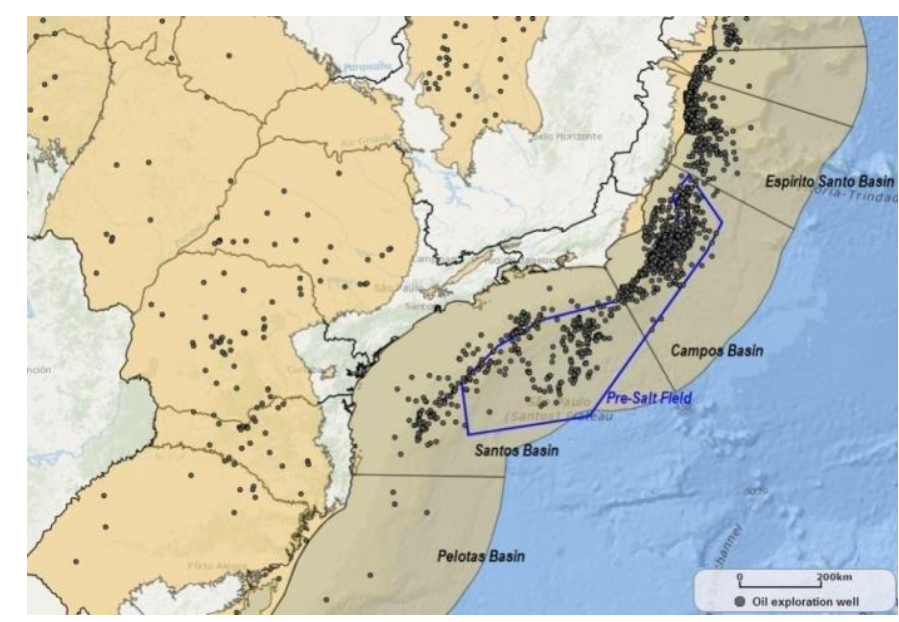

Figure 7. The pre-salt area in sedimentary basins at the southeast of Brazil and respective operational oil wells in 2018. Source: ANP (2020).

The offshore oil production data in the Santos Basin are even more impressive than those collected before pre-salt. Since the start of the pre-salt oil exploration, São Paulo state increased its production from 89 thousand $\mathrm{m}^{3}$ per year (2000) to 16 million $\mathrm{m}^{3}$ per year (2016), and the expectation for 2017 has exceeded 18 million $\mathrm{m}^{3}$ per year (ANP, 2018).

In 2017, the Campos Basin had a total of 863 offshore drilled wells, 537 of which produced oil (Figure 7). On the other hand, the Santos Basin presented lower values, with 114 offshore drilled wells and 55 in production at that time (ANP, 2018). Moreover, there are more than 977 potential risk points of leakage in the domain analyzed in this study, without considering the possibility of spillage due to ship leakage.

\subsection{Brazilian Offshore Oil Spill}

A four-hour leak oil spill in the Guanabara Bay pipeline, Rio de Janeiro, on January 18, 2000 , struck the nearby mangrove swamp, causing significant damage to the environment. This accident hampered essential activities such as fishing and tourism, and provoked a direct impact on the design and planning of Brazilian environmental guidelines for that sector (Ferreira et al., 2003).

In order to control such accidents, Brazilian Federal Law 9966 was enacted on April 28, 2000 to regulate the prevention, control and monitoring of the pollution caused by the release of substances into water, and was overseen by the National Environment Council (CONAMA) Resolution 293 on December 12, 2001 (Ferreira et al., 2003). This resolution defines, among 
other things, the Individual Emergency Plan, which includes identification of risks of potential sources of spills, discussion of accidental hypotheses, vulnerability analysis, and definition of potentially affected areas. The changes in the Brazilian legislation were essential for a better management of the sector (Zacharias, 2017). Although (Brazilian Environmental Agency (IBAMA) has been receiving oil spill communications since 2001, only in 2010 did this Agency begin to include that information in a database (Maggi et al., 2014).

The Guanabara Bay pipeline accident (January 18, 2000), considering the Brazilian reality, was an event comparable to Exxon-Valdez. The Deepwater Horizon spill was a warning for the potential risk embedded in spills in the basins of Campos and Santos (Table 1). The Brazilian statistics for oil spills are not as accurate and complete as those provided by the Bureau of Ocean Energy Management (BOEM). An initial table listing the main accidents on the Brazilian coast between 1960 and 2004 was elaborated by Souza Filho (2006), and continued to be amplified until 2016 (Table 1). The number of accidents (2012-14) involving oil discharge, harmful or dangerous substances comprised approximately 374 events, with a total spilled volume of $140 \mathrm{~m}^{3}$ (Santos et al., 2017). Although the volume of these discharges was relatively small, some of the spilled substances, such as pure acetic acid, liquid xylene, and others, were potentially very dangerous for marine life (Santos et al., 2017).

The Sinclair spill (1960) was one of the 50 largest offshore spills in the world until 2010 (Fingas, 2010). It was the first significant accident in Brazilian waters (Table 1), with spilled volume far superior to all subsequent spills. However, due to political, historical and media conditions, it did not have the same impact on public opinion. On the other hand, the smaller pipeline spill in Rio de Janeiro, 2000 (Table 1), had historical importance, resulting in significant changes in Brazilian environmental legislation (Ferreira et al., 2003).

The unknown South Atlantic oil spill (2019) was first identified on the Brazilian coast on August $30^{\text {th }} 2019$, reaching 4,334 $\mathrm{km}$ of coastline. This disaster is considered the worst oil spill in Brazil's history and one of the largest on record in the world. The crude oil spill has compromised the health of 360,000 artisanal fishers in Northeast Brazil, besides those living on the coast in the states of Espírito Santo and Rio de Janeiro in the Southeast. Considering the territorial extension and affected population, this oil spill disaster is the equivalent of hundreds of Brazilian refineries and petrochemical factories having their workplaces contaminated and being closed down due to sudden, uncontrolled exposure to petroleum and aromatic hydrocarbons, and without the health sector's protection (Pena et al., 2020).

The worldwide expectation is to keep decreasing this type of accident through improved technologies of processes, control systems and integrated management. Furthermore, in order to maintain the downward trend of these accidents, even considering increased production, continuous investments in technology, knowledge and innovation must be made (Table 2).

Brazilian offshore oil exploration follows a worldwide trend of increasing production and reducing accidents (Table 1 and 2), but even with significant rates of accident reduction, recent events like the Deepwater Horizon (Beyer et al., 2016) and the Sanchi collision (Yin et al., 2018) show that oil extraction still presents many environmental risks due to the large number of oil operations over the oceans around the world.

Pre-Salt oil extraction in ultra-deep waters requires drilling technology capable of overcoming 2,100 meters of seawater and drilling more than 5,000 meters under the seafloor (totaling more than 7,100 meters deep) with at least 2,000 m of salt. In these conditions, the continuous improvement of the management of all risks involved in the oil extraction becomes essential (Beltrão et al., 2009).

The depths involved in the pre-salt field exploration are similar to those found in the Macondo oil field, which resulted in the Deepwater Horizon accident (Beyer et al., 2016), showing the environmental risks involved in ultra-deep oil production. 
Table 1. Data on the main accidents with oil products spills in Brazil from 1960 to 2016.

\begin{tabular}{|c|c|c|c|}
\hline Year & Source & Site & Spilled quantity $\left(\mathrm{m}^{3}\right)$ \\
\hline 1960 & Sinclair Petrolore & Near Brazilian Coast & 66,000 \\
\hline 1974 & Takimyia Maru & São Sebastião Channel, SP & 7,000 \\
\hline 1974 & Esso Garden State & Indefinite terminal & 5,800 \\
\hline 1975 & Tarik Ibn Ziyad & Guanabara Bay, RJ & $7,000-18,000$ \\
\hline 1978 & Brazilian Marina & São Sebastião Channel, SP & $6,000-40,000$ \\
\hline 1978 & Aminona & Banco do Meio, ZEE & 23,000 \\
\hline 1979 & Gunvor MAERSK & Amazonas River & $12,000-17,000$ \\
\hline 1983 & Pipeline & São Sebastião - Cubatão, SP & 2,500 \\
\hline 1985 & Marina & São Sebastião, SP & $2,000-3,000$ \\
\hline 1986 & Brotas & Litoral RJ & 1,600 \\
\hline 1994 & Pipeline & São Sebastião - Cubatão, SP & 2,700 \\
\hline 1997 & Pipeline & Guanabara Bay, RJ & $1,000-3,000$ \\
\hline 2000 & Pipeline & Guanabara Bay, RJ & 1,300 \\
\hline 2000 & Pipeline & Barigüi River, PR & 4,000 \\
\hline 2001 & Platform P36 & Campos Basin & 1,500 \\
\hline 2004 & Pipeline & São Sebastião - Cubatão, SP & Unknown \\
\hline 2004 & Vicuña & Paranaguá Bay, PR & 6,500 \\
\hline 2011 & Chevron Platform & Campos Basin & 3,700 \\
\hline 2012 & Transpetro Pipeline & Tramandaí, RS & 140 \\
\hline 2012 & Dynamic Producer & Santos Basin & 160 \\
\hline 2014 & Transpetro Pipeline & Tramandaí, RS & 24 \\
\hline 2016 & Transpetro Pipeline & Tramandaí, RS & 150 \\
\hline 2019 & P58 - Pipeline & Jubarte Field, ES & 260 \\
\hline 2019 & Equatorial Atlantic & South Atlantic & Unknown \\
\hline
\end{tabular}

Source: adapted from Souza Filho (2006) and Zacharias (2017). 
Table 2. Accident statistics with volume spilled above 1,000 bbl during the handling operations around the world from 1974 to 2018.

\begin{tabular}{ccccc}
\hline Period & $\begin{array}{c}\text { Crude Oil Handled } \\
\text { (in 10 }\end{array}$ & Spills Occurred & Number of Spills per year & $\begin{array}{c}\text { Spills per } \\
10^{12} \text { bbl Handled }\end{array}$ \\
\hline $1974-1979$ & 62.13 & 113 & 18.8 & 1.82 \\
$1980-1989$ & 74.97 & 90 & 9.0 & 1.20 \\
$1990-1999$ & 102.55 & 73 & 7.3 & 0.71 \\
$2000-2009$ & 134.14 & 20 & 2.0 & 0.15 \\
$2010-2018$ & 111.07 & 12 & 1.3 & 0.11 \\
\hline
\end{tabular}

Source: BSEE Report (US, 2016) and ITOPF report (ITOPF, 2019).

\subsection{Oil Pollution in Brazilian Coastal Waters}

Oil pollution in water can occur in many ways, either directly by discarding oil from platforms and ships, or indirectly, by discharged water from cleaning tanks and piping production, or oil removal from platforms and equipment by the rain. Industrialization of municipalities near offshore oil fields also results in new direct and indirect sources of estuarine and coastal water pollution. Anthropogenic emissions have been increasing the concentrations of oil derivative pollutants in coastal waters, as well as across drainage basins and in marine waters. The mussels in those waters have been considered significant environmental indicators of sea life contamination by toxic components of oil (Santiago et al., 2016).

The effluent emissions in Brazilian seawaters is regulated by CONAMA resolution $357 / 2005$, which defines the emission limit less than $10 \mathrm{mg} \mathrm{l}^{-1}$ of TOC (total organic carbon) in treated effluent without dilution. The emission limit is a way of minimizing the environmental impact, since the volume of water produced on a platform is of the same magnitude as the volume of oil produced. Even though the emission limit is low, the large volume of produced water discarded at sea results in a large amount of oil being thrown into the sea every day.

Although Guanabara Bay is of great environmental and socio-economic importance on Brazilian southeastern coast, its current state of degradation poses risks in its surroundings not only to the human population, but also to the bay ecosystem. Even though several recovery programs involving Guanabara Bay have started, the available data indicate that they have not achieved their goals yet (Soares-Gomes et al., 2016).

Macaé municipality, on a coastal area, is located $150 \mathrm{~km}$ from the Rio de Janeiro state refineries (REDUC, REFIT and COMPERJ) and receives $16 \%$ of oil and 19.7 million $\mathrm{m}^{3}$ of gas from Campos Basin (ANP, 2018). Water contamination was evaluated using Brown mussels from four sites along the Macaé coast: Macaé River Estuary (MRE), Campista Beach (BC), Santana Island (SI) and Pedrinhas Beach (PB). MRE and BC are located close to the urban area, while SI and PB, $8 \mathrm{~km}$ far from the urban area (Santiago et al., 2016). The mussels presented high contamination values of polycyclic aromatic hydrocarbons (PAHs) at MRE, revealing an incidence of significant oil contamination. On the other hand, $\% \sum 16 \mathrm{PAHs}$ related to the total content were higher in remote sites (SI and PB) than in urban areas (MRE and BC). These results unveiled a possible initial oil contamination in unsuspected sites (Table 3), since PAH ratios in mussels are influenced by petrogenic sources (Santiago et al., 2016).

The Paranaguá Bay, in Santos Basin, is an estuary with two significant exportation ports (Paranaguá and Antonina) and about 11\% movement of petroleum-derived products (Brasil, 2018). In Paranaguá Bay, the total PAHs levels in sediments (133.61 $\mathrm{ng} \mathrm{g}^{-1}$ ) and water 
$\left(162.37 \mu \mathrm{g} \mathrm{l}^{-1}\right)$ represented lower contamination; while the concentrations found in dry weight plankton (2096.10 $\mathrm{ng} \mathrm{g}^{-1}$ ) and fish (2055.00 $\mathrm{ng} \mathrm{g}^{-1}$ ) were alarmingly higher (Froehner et al., 2018). In sections of Paranaguá Bay, labeled as unpolluted, there were lower contaminant concentrations in water and sediments. The values obtained in organisms were more than $1000 \%$ higher than those obtained in sediments due to the bioaccumulation process (Froehner et al., 2018).

Table 3. Data compilation for total PAH concentrations in some environmental matrixes of the Brazilian Coast near offshore oil fields from 2016 to 2018 (in dry weight conditions).

\begin{tabular}{|c|c|c|c|c|}
\hline Site & Matrix & Component & Range (ng g ${ }^{-1}$ ) & Author \\
\hline São Paulo Estuary/BA & Sediment & $\sum$ PAH & $12-1,825$ & Nascimento et al. (2017) \\
\hline Todos Santos Bay/BA & Sediment & $\sum$ PAH & $13-511$ & Santos et al. (2017) \\
\hline Camamu Bay/BA & Sediment & $\sum \mathrm{PAH}$ & $1-313$ & Pedreira et al. (2017) \\
\hline Vitória/ES & Sediment & $\sum$ PAH & $89-432$ & Pinheiro et al. (2017) \\
\hline Campos Basin/RJ & Fish & $\begin{array}{c}\sum \mathrm{PAH} \\
\sum 16 \mathrm{PAH}\end{array}$ & $\begin{array}{l}21-600 \\
10-148\end{array}$ & Lourenço et al. (2018) \\
\hline Macaé Coast/RJ & Brown Mussels & $\begin{array}{c}\sum \mathrm{PAH} \\
\sum 16 \mathrm{PAH}\end{array}$ & $\begin{array}{c}317-6,101 \\
79-169\end{array}$ & Santiago et al. (2016) \\
\hline Sepetiba/RJ & Sediment & $\sum$ PAH & $45-3,138$ & Pinheiro et al. (2017) \\
\hline Guanabara Bay/RJ & Sediment & $\sum$ PAH & $101-4,148$ & Camargo et al. (2017) \\
\hline Rio de Janeiro/RJ & Sediment & $\sum$ PAH & $259-8,064$ & Pinheiro et al. (2017) \\
\hline Angra dos Reis/RJ & Sediment & $\sum \mathrm{PAH}$ & $48-2,626$ & Pinheiro et al. (2017) \\
\hline São Sebastião/SP & Bentic & $\sum \mathrm{PAH}$ & $1-524$ & Checon et al. (2018) \\
\hline São Sebastião/SP & Sediment & $\sum \mathrm{PAH}$ & $1-621$ & Kim et al. (2018) \\
\hline São Sebastião/SP & Sediment & $\sum \mathrm{PAH}$ & $201-1,494$ & Pinheiro et al. (2017) \\
\hline Santos/SP & Sediment & $\sum \mathrm{PAH}$ & $181-3,397$ & Pinheiro et al. (2017) \\
\hline Paranaguá Bay/PR & $\begin{array}{l}\text { Water } \\
\text { Sediment } \\
\text { Plancton }\end{array}$ & $\sum \mathrm{PAH}$ & $\begin{array}{c}51-162 \\
15-133 \\
175-2,096\end{array}$ & Froehner et al. (2018) \\
\hline Laranjeiras Bay/PR & Sediment & $\sum$ PAH & $1-8$ & Camargo et al. (2017) \\
\hline Itajaí-Açu/SC & Sediment & $\sum \mathrm{PAH}$ & $64-1,459$ & Frena et al. (2017) \\
\hline
\end{tabular}

Source: adapted from Pinheiro et al. (2017).

The Laboratory of Applied Ichthyology (LAB PEIXE - UVV) conducted experiments with Echinometralucunter to determine the decrease in fertilization rates and reduction of larvae pluteus development rate due to concentrations of benzene, toluene, ethylbenzene and xylenes (BTEX) and PAHs in water (Pereira et al., 2018).

Concentrations of PAHs in Paranaguá Bay water $\left(162.37 \mu \mathrm{g} \mathrm{l}^{-1}\right)$ indicated a worrying situation compared to results of toxicity tests conducted by LAB PEIXE (Pereira et al., 2018), 
with potential decreases of $80-90 \%$ of the fertilization and larvae pluteus development rates. In biota, the accumulation is associated with the level in the trophic chain and lipid content; plankton presented 39\% and fish 38\% of the total PAHs quantified (Froehner et al., 2018).

A study conducted with fish samples (Cathorops spixii and Atherinella brasiliensis) in Paranaguá Bay showed elevated levels of contamination affecting both fish species (Santos et al., 2018). The analyses showed five times higher concentrations of two-ringed PAH metabolites in the bile of the two fish species in Paranaguá Bay in comparison to those in the control site (Santos et al., 2018).

The PAHs pollution levels were investigated in the ocean by produced water discharge around the P19 and P40 offshore platforms in Campos Basin, using two species of fish, Caranxcrysos and Tylosurusacus (Lourenço et al., 2018). The non discharging produced water platform P25 was taken as an uncontaminated reference. The average concentration of PAH observed in the C. crysos muscle tissue was $219.38 \mathrm{ng} \mathrm{g}^{-1}$ (P40), followed by $68.26 \mathrm{ng} \mathrm{g}^{-1}$ (P19) and $12.95 \mathrm{ng} \mathrm{g}^{-1}$ (P25, control group). The average value observed for $\mathrm{T}$. acus was $42.21 \mathrm{ng} \mathrm{g}^{-1}$ (P40), followed by $40.07 \mathrm{ng} \mathrm{g}^{-1}$ (P19) and $18.04 \mathrm{ng} \mathrm{g}^{-1}$ (P25, control group). These results with fish study confirmed a previous bioaccumulation of PAH by produced water discharge detected with bivalves under the platforms (P19 and P40) at Campos Basin (Lourenço et al., 2018). Produced water had small quantities of oil and derivatives, being usually well diluted because of the continuous discharge. The bioaccumulation of tested fish could be considered as minimally contaminated with PAH, even if the concentration of PAH in the muscle tissues of both species were low and not genotoxic (Lourenço et al., 2018).

A study conducted at seven sites, classified in three groups (Praia Grande, Ubatuba and Espírito Santo), along the southeastern coast of Brazil has shown that green sea turtles (Chelonia mydas) may be developing Fibropapillomatosis (FP) due to exposure to PAH, especially because of phenanthrene (Vilca et al., 2018). Turtles of the Espírito Santo Group developed more Fibropapillomatosis (FP) individually than those in other groups, 17 with an FP of 19 C. mydas collected. In general, Espírito Santo presented more environmental problems than other sites. These results might be due to its association with a large port, water discharge and heavy industry, which could have explained the individuals with more FP in this group (Vilca et al., 2018).

The studies above showed evidence of oil contamination with PAH low concentrations, even in smaller areas far from large industrial centers and without accidental spills. The total PAHs levels presented significant variability from studies between 2016 and 2018 in the Brazilian coast waters near offshore oil exploitation fields, showing higher concentrations near harbors than in the other position sites (Table 3). This data compilation represents an initial diagnosis of water quality conditions and its contamination by oil along the Brazilian southeastern coast. The PAH levels found in the studies were quite heterogeneous (Table 2), indicating that pollution is not yet massively spread throughout the coast, being concentrated only in few areas, and just detectable at low levels in areas of preservation.

\section{CONCLUSIONS}

The Brazilian offshore oil production follows the worldwide trend of increasing production and reducing accidents, but despite the significant accident reduction rates, events like those of Deepwater Horizon, show environmental risks of ultra-deep oil exploration.

Campos and Santos Basins are the most important offshore oil reserves under exploration in Brazil, with huge potential to be explored in the next decades, mainly concerning the oil located in the pre-salt layer with large environmental risks resulting from ultra-deep oil exploration. A large part of the exploration is over coastal platforms, in very shallow waters, which makes the dispersion and dilution of heavy hydrocarbons difficult, influencing some 
bioaccumulation found in marine life.

Studies of the geophysical aspects of the region as well as the possible environmental impacts are still very segmented by areas of knowledge, but hold great potential for more integrated, multi- and interdisciplinary studies. The onset of the environmental licensing phases of the wells and of prevention of accidents, plus studies on how to remediate contaminated areas, must be integrated in the future oceanic engineering projects and platforms.

The environmental description of the Brazilian southeastern coast shows that the intense atmospheric events due to the potential formation of cyclones in the region, added to the high velocity of the Brazil Current meanders are good for oil pollution dispersion, contributing unfavorably to the exploration of that region. These conditions are not so extreme when compared to the Alaskan and Mexican Gulfs and, therefore, Brazilian platforms are not at severe risk due to the weathering. However, exploration of the pre-salt fields brings many risks because of the ultra-deep distances, as evidenced by previous accidents at the Chevron platform in the Campos Basin (3,700 $\mathrm{m}^{3}$ of oil spilled in 2011) and Dynamic Producer in the Santos Basin $\left(160 \mathrm{~m}^{3}\right.$ of oil spilled in 2012).

Brazil still does not have a reliable database to unify all oil spill information reported to IBAMA, despite the attempt made in 2014 by Maggi. The creation of a database substantiated on federal Law $\mathrm{n}^{\mathrm{o}} 12.527 / 2011$ would allow broad access to existing information, increasing knowledge and allowing further studies on the environmental impacts of oil spills. This database could also have data on the allowed discharge of produced water at each point of launch along the Brazilian coast, according to the environmental licenses issued.

Despite efforts of environmental impact assessment and effluent emission limits, there are many studies showing some levels of PAH contamination in environmental matrices along the coast. It is possible that the continuous emission of effluents, uncontrolled oil spills, large unremoved oil spills, untreated ballast water, oil removal from platforms and equipment by the rain, are creating (or increasing) PAH background concentrations along the coast. Low-level emissions in produced water causes a residual impact in water quality However, the large amounts of oil wells and their arising operations, such as transport, ship-to-ship, among others, are resulting in some background pollution and not only in residual impacts.

The polycyclic aromatic hydrocarbons (PAH) pollution levels evaluation have been showing that there are still preserved areas on Brazilian coast which are not risk free, and contamination levels could increase due to the growth of offshore oil production.

\section{ACKNOWLEDGMENTS}

The authors thank the financial support - CAPES-PROEX (Post-graduation program in Meteorology), fellowship CNPq. Department of Atmospheric Sciences, Institute of Astronomy, Geophysics and Atmospheric Sciences, University of São Paulo, IAG/USP.

\section{REFERENCES}

ALVES, T. M.; FETTER, M.; LIMA, C.; CARTWRIGHT, J. A.; COSGROVE, J.; GANGÁ, A.; QUEIROZ, C. L.; STRUGALE, M. An incomplete correlation between pre-salt topography, top reservoir erosion, and salt deformation in deep-water Santos Basin (SE Brazil). Marine and Petroleum Geology, v. 79, p. 300-320, 2017. https://dx.doi.org/10.1016/j.marpetgeo.2016.10.015

AMBRIZZI, T.; FERRAZ, S. E. An objective criterion for determining the South Atlantic Convergence Zone. Frontiers in Environmental Science, v. 3, p. 23. 2015. https://dx.doi.org/10.3389/fenvs.2015.00023 
AGÊNCIA NACIONAL DO PETRÓLEO (Brasil). Anuário Estatístico Brasileiro do Petróleo, Gás Natural e Biocombustíveis. Rio de Janeiro, 2018.

AGÊNCIA NACIONAL DO PETRÓLEO (Brasil). Webmapas. Available at: http://webmaps.anp.gov.br/mapas/Lists/DSPAppPages/MapasBrasil.aspx Access: 24 Feb. 2020.

BARROS, V.; GONZALEZ, M.; LIEBMANN, B.; CAMILLONI, I. Influence of the South Atlantic convergence zone and South Atlantic Sea surface temperature on interannual summer rainfall variability in Southeastern South America. Theoretical and Applied Climatology, v. 67, n. 3-4, p. 123-133, 2000. https://dx.doi.org/10.1007/s007040070002

BELTRÃO, R. L.; SOMBRA, C. L.; LAGE, A. C.; FAGUNDES-NETTO, J. R.; HENRIQUES, C. C. Challenges and new technologies for the development of the pre-salt cluster, Santos Basin, Brazil. In: OFFSHORE TECHNOLOGY CONFERENCE, 4-7 May 2009, Houston, Texas. Papers[...] OTC, 2009. p. 1-11. https://dx.doi.org/10.4043/19880-MS

BEYER, J.; TRANNUM, H. C.; BAKKE, T.; HODSON, P. V.; COOLIER, T. K. Environmental effects of the Deepwater Horizon oil spill: A review. Marine Pollution $\begin{array}{llllllll}\text { Bulletin, } & \text { v. } & 11 & 0, & \text { n. } & 1, & \text { p. } & 28-51,\end{array}$ https://dx.doi.org/10.1016/j.marpolbul.2016.06.027

BRASIL. Ministério dos Transportes, Portos e Aviação Civil. Complexo Portuário de Paranaguá e Antonina - Sumário Executivo. Paranaguá, 2018.

BRASIL. Presidência da República. Constituição da República Federativa do Brasil de 1988. Diário Oficial [da] União: seção 1, Brasília, DF, n. 191-A, p. 1-32, 05 out. 1988.

CAMARGO, M. Z.; SANDRINI-NETO, L.; CARREIRA, R. S.; CAMARGO, M. G. Effects of hydrocarbon pollution in the structure of macrobenthic assemblages from two large estuaries in Brazil. Marine Pollution Bulletin, v. 125, p. 66-76, 2017. https://dx.doi.org/10.1016/j.marpolbul.2017.07.074

CARVAlHO, L. M.; JONES, C.; LIEBMANN, B. The South Atlantic Convergence Zone: Intensity, Form, Persistence, and Relationships with Intraseasonal to Interannual Activity and Extreme Rainfall. Journal of Climate, v. 17, p. 88-108, 2004. https://dx.doi.org/10.1175/1520-0442(2004)017<0088:TSACZI >2.0.CO;2

CHECON, H. H.; CORTE, G. N.; MUNIZ, P.; BRAUKO, K. M.; DI DOMENICO, M.; BÍCEGO, M. C.; SIEGLE, E.; FIGUEIRA, R. C. L.; AMARAL, A. C. Z. Unraveling the performance of the benthic index AMBI in a subtropical bay: The effects of data transformations and exclusion of low-reliability sites. Marine Pollution Bulletin, v. 126, p. 438-448, 2018. https://dx.doi.org/10.1016/j.marpolbul.2017.11.059

COELHO, A. C. Operational risk in the decommissioning of fixed maritime oil exploration and production unit. 2010. Masters Dissertation - Fluminense Federal University - UFF, Technological Center, Niterói, 2010.

CPRM. Bacias sedimentares da margem continental brasileira. 2018. Available at: http://www.cprm.gov.br/publique/media/recursos_minerais/livro_geo_tec_rm/capIIIg.pdf_Access: 2020.

DEVUYST, D. Linking impact assessment and sustainable development at the local level: the introduction of sustainability assessment systems. Sustain. Dev. 8 (2),67-78, 2000. 
DOMINGOS, D. de O. Bacias Sedimentares em KMZ. 28 Jul. 2011. Available at: http://www.danilodomingos.com.br/bacias_sedimentares_kmz.php Access: 2020.

DUTRA, L. M. Subtropical cyclones on the South Atlantic: analysis of the dynamic structure of events. 2012. Master Thesis - Institute of Astronomy, Geophysics and Atmospheric Sciences, University of São Paulo, São Paulo, 2012.

FERREIRA, H. O.; CABRAL, A.; SOUZA JUNIOR, Á. An application of worst-case scenario concept in oil spill response planning for offshore drilling operation in Brazil. International Oil Spill Conference Proceedings, v. 2003, n. 1, p. 371-376, 2003. http://dx.doi.org/10.7901/2169-3358-2003-1-i

FINGAS, M. Oil spill science and technology. Prevention, Response and Clean-up. $1^{\text {st }}$ ed. Houston: Gulf Professional Publishing, 2010.

FRENA, M.; BATAGLION, G. A.; SANDINI, S. S.; KUROSHIMA, K. N.; EBERLIN, M. N.; MADUREIRA, L. Distribution and sources of aliphatic and polycyclic aromatic hydrocarbons in surface sediments of Itajaí-Açu estuarine system in Brazil. Journal of Brazilian Chemical Society, v. 28, n. 4, p. 603-614, 2017. https://dx.doi.org/10.21577/0103-5053.20160205

FROEHNER, S.; RIZZI, J.; VIEIRA, L. M.; SANEZ, J. PAHs in water, sediment and biota in an area with port activities. Archives of Environmental Contamination and Toxicology, v. 75, p. 236-246, 2018. https://dx.doi.org/10.1007/s00244-018-0538-6

GILLILAND, J. M., KEIM, B. D. Position of the South Atlantic Anticyclone and Its Impact on Surface Conditions across Brazil. Journal of Applied Meteorology and Climatology, v. 57, n. 3, p. 535-553, 2018. https://dx.doi.org/10.1175/JAMC-D-17-0178.1

GLASSON, J.; THERIVEL, R. Introduction to Environmental Impact Assessment. $4^{\text {th }}$ ed. London: Routledge, 2012. p. 6-10.

GOOS-BRASIL. Programa Nacional de Boias. Available at: http://www.goosbrasil.org/pnboia/dados/ Access: 24 Feb. 2020.

ITOPF. Oil Tanker Spill Statistics. 2019. Available at: https://www.itopf.org/fileadmin/data/Documents/Company_Lit/Oil_Spill_Stats_2019.p df. Access 2020.

KIM, B.; BÍCEGO, M.; TANIGUCHI, S.; SIEGLE, E.; OLIVEIRA, R.; ALCÁNTARACARRIÓ, J.; FIGUEIRA, R. Organic and inorganic contamination in sediments from AraçáBay, São Sebastião, Brazil. Ocean and Coastal Management, v. 164, p. 42-51, 2018. https://dx.doi.org/10.1016/j.ocecoaman.2017.12.028

LOURENÇO, R. A.; FRANCIONI, E.; SILVA, A.; MAGAlHÃES, C. A.; GALlOTTA, F. D.; OLIVEIRA, F. F.; SOUZA, J. M., ARAÚJO, L. F. M.; ARAÚJO, L. P.; ARAÚJOJR, M. A. G.; MENICONI, M. F. G.; LOPES, M. A. F. S. B. G. Bioaccumulation study of produced water discharges from Southeastern Brazilian offshore petroleum industry using Feral Fishes. Archives of Environmental Contamination and Toxicology, v. 74, n. 3, p. 461-470, 2018. https://dx.doi.org/10.1007/s00244-018-0510-5

MAGGI, P.; MORGADO, C. R.; ALMEIDA, J. C. Offshore oil spill incidents: creating a database in Brazil. International Oil Spill Conference Proceedings, v. 2014, n. 1, p. 26-30, 2014. https://dx.doi.org/10.7901:2169-3358-2014.1.26 
MATTOS, R. A. Meso and large scale features of the Brazilian current off the Brazilian southeast. 2006. Masters Dissertation - Oceanographic Institute, São Paulo University, São Paulo, 2006.

MELLO, U. T.; KARNER, G. D.; ANDERSON, R. N. Role of salt in restraining the maturation of subsalt source rocks. Marine and Petroleum Geology, v. 12, n. 7, p. 697-716, 1995. https://dx.doi.org/10.1016/0264-8172(95)93596-V

NASCIMENTO, R. A.; ALMEIDA, M.; ESCOBAR, N.; FERREIRA, S.; MORTATTI, J.; QUEIROZ, A. Sources and distribution of polycyclic aromatic hydrocarbons (PAHs) and organic matter in surface sediments of an estuary under petroleum activity influence, Todos os Santos Bay, Brazil. Marine Pollution Bulletin, v. 119, p. 223-230, 2017. https://dx.doi.org/10.1016/j.marpolbul.2017.03.069

NOAA Physical Sciences Laboratory. Composites. Available at: https://www.esrl.noaa.gov/psd/cgi-bin/data/composites Access: 24 Feb. 2020.

OLIVEIRA, A. I. Technical-economic analysis of $\mathrm{CO}_{2}$ injection in reservoirs with Brazilian pre-salt characteristics. 2016. Masters Dissertation - Rio Grande do Norte Federal University, Natal, 2016.

PAPATERRA, G. E. Pre-Salt: Geological conceptualization on a new exploratory frontier in Brazil. 2010. Masters Dissertation - Departament of Geology, Rio de Janeiro Federal University, Rio de Janeiro, 2010.

PEDREIRA, R.; BARROS, F.; FARIAS, C.; WAGENER, A.; HATJE, V. A tropical bay as a reference area defined by multiple lines of evidence. Marine Pollution Bulletin, v. 123, p. 291-303, 2017. https://dx.doi.org/10.1016/j.marpolbul.2017.08.041

PELLIZZON, M. M. Characterization of Seismic Units, Sedimentary Processes and Age of Almirante Camara Canyon, Campos Basin. 2005. 84 f. Masters Dissertation - Federal Fluminense University, Niteroi, 2005.

PENA, P. G. L.; NORTHCROSS, A. L.; LIMA, M. A. G.; RÊGO, R. C. F. The crude oil spill on the Brazilian coast in 2019: the question of public health emergency. Cadernos de Saúde Pública, v. 36, n. 2, 2020. https://dx.doi.org/10.1590/0102-311x00231019

PEREIRA, T. M.; MERÇON, J.; PASSOS, L. S.; COPPO, G. C.; LOPES, T.; CABRAL, D. S.; SCHERER, R.; CHIPPARI-GOMES, A. R. Effects of the water-soluble fraction of diesel oil (WSD) on the fertilization and development of a sea urchin (Echinometralucunter). Ecotoxicology and Environmental Safety, v. 162, p. 59-62, 2018. https://dx.doi.org/10.1016/j.ecoenv.2018.06.040

PETERSON, R. G.; STRAMMA, L. Upper-level circulation in the South Atlantic Ocean. Progress in Oceanography, v. 26, n. 1, p. 1-73, 1991. https://dx.doi.org/10.1016/00796611(91)90006-8

PETROBRAS. Bacia de Santos. 2018. Available at: http://www.petrobras.com.br/pt/nossasatividades/principais-operacoes/bacias/bacia-de-santos.htm Access: 2020.

PINHEIRO, P.; MASSONE, C. G.; CARREIRA, R. S. Distribution, sources and toxicity potential of hydrocarbons in harbor sediments: A regional assessment in SE Brazil. $\begin{array}{llllll}\text { Marine Pollution Bulletin, v. 120, p. } & 617 .\end{array}$ https://dx.doi.org/10.1016/j.marpolbul.2017.04.049 
REBOITA, M. S.; NIETO, R., GIMENO, L., ROCHA, R. P., AMBRIZZI, T., GARREAUD, R., KRUGER, L. F. Climatological features of cutoff low systems in the Southern Hemisphere. Journal of Geophysical Research, v. 115, 2010a. https://dx.doi.org/10.1029/2009JD013251

REBOITA, M. S.; ROCHA, R. P.; AMBRIZZI, T.; SUGAHARA, S. South Atlantic Ocean cyclogenesis climatology simulated by regional climate model (RegCM3). Climate Dynamics, v. 35, n. 7-8, p. 1331-1347, 2010b. https://dx.doi.org/10.1007/s00382-009-0668-7

RICCOMINI, C.; SANT'ANNA, L. G.; TASSINARI, C. C. Pré-sal: geologia e exploração. Revista USP, v. 95, p. 33-42, 2012. https://dx.doi.org/10.11606/issn.23169036.v0i95p33-42

ROCHA, R. P.; REBOITA, M. S.; GOZZO, L. F.; DUTRA, L. M.; JESUS, E. M. Subtropical cyclones over the oceanic basins: a review. Annals of the New York Academy of Sciences, v. 1436, p. 138-156, 2019. https://dx.doi.org/10.1111/nyas.13927

ROOS, C.; CILliERSA, D. P.; RETIEF, F. P.; AlBERTS, R. C.; BOND, A. J. Regulators' perceptions of environmental impact assessment (EIA) benefits in a sustainable development context. Environmental Impact Assessment Review, v. 81, 2020. https://dx.doi.org/10.1016/j.eiar.2019.106360

SANTIAGO, I. U.; MOLISANI, M. M.; NUDI, A. H.; SCOFIELD, A. L.; WAGENER, A. L.; LIMAVERDE FILHO, A. M. Hydrocarbons and trace metals in mussels in the Macaécoast: Preliminary assessment for a coastal zone under influence of offshore oil field exploration in southeastern Brazil. Marine Pollution Bulletin, v. 103, p. 349-353, 2016. https://dx.doi.org/10.1016/j.marpolbul.2015.12.034

SANTOS, G. S.; PIANCINI, L. D. S.; TINCANI, F. H.; KLINGELFUS, T.; YAMAMOTO, F. Y.; RIBEIRO, C. A. O.; GUILOSKI, I. C.; ASSIS, H. C. S.; CESTARI, M. M. Liver damage in two neotropical fish species from a polluted estuarine area. Ecotoxicology and Environmental Contamination, v. 13, n. 1, p. 39-50, 2018. https://dx.doi.org/10.5132/eec.2018.01.05

SANTOS, M. D.; AMARAL, V. N.; MARTINS, E. R.; QUINTAL, R. S.; MAGNO, B. D. Incidentes de descarga de óleo, substâncias nocivas ou perigosas na bacia de Campos: uma análise do método de análise preliminar de risco. Revista da Universidade Vale do Rio Verde, v. 15, n. 1, p. 94-105, 2017. https://dx.doi.org/10.5892/ruvrd.v15i1.3712

SILVEIRA, I. C. The current system of Brazil in the Campos basin, RJ. 2007. Professor's Thesis - Oceanographic Institute - São Paulo University, São Paulo, 2007.

SILVEIRA, I. C.; MIRANDA, L. B.; BROWN, W. S. On the origins of the North Brazil Current. Journal of Geophysics Research, v. 99, p. 22501-22512, 1994. https://dx.doi.org/10.1029/94JC01776

SILVEIRA, I. C.; SCHMIDT, A. C.; CAMPOS, E. J.; GODOI, S. S.; IKEDA, Y. A corrente do Brasil ao largo da costa leste brasileira. Revista Brasileira de Oceanografia, v. 48, n. 2, p. 171-183, 2000. https://dx.doi.org/10.1590/S1413-77392000000200008

SIQUEIRA, J. R.; MACHADO, L. A. Influence of the frontal systems on the day-to-day convection variability over South America. Journal of Climate, v. 17, p. 1754-1766, 2004. https://dx.doi.org/10.1175/1520-0442(2004)017<1754:IOTFSO>2.0.CO.2 
SNYDER, H. Literature review as a research methodology: An overview and guidelines. Journal of Business Research, v. 104, p. 333-339, 2019. https://dx.doi.org/10.1016/j.jbusres.2019.07.039

SOARES, F. L. Study of the superficial ocean circulation on the southeast coast of Brazil through hydrodynamic modeling. Masters Dissertation - COPPE, Rio de Janeiro Federal University, Rio de Janeiro, 2014.

SOARES-GOMES, A.; GAMA, B.; BAPTISTA NETO, J. A.; FREIRE, D. G.; CORDEIRO, R. C.; MACHADO, W.; BERNARDES, M. C.; COUTINHO, R.; THOMPSON, F. L.; PEREIRA, R. C. An environmental overview of Guanabara Bay, Rio de Janeiro. Regional

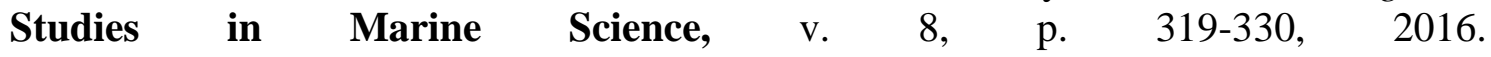
https://dx.doi.org/10.1016/j.rsma.2016.01.009

SOUZA FILHO, A. M. National contingency plans for oil spill care: Analysis of countries representative of the Americas for implementation in the case of Brazil. Masters Dissertation - Rio de Janeiro Federal University, Rio de Janeiro, 2006.

TASCHETTO, A. S.; WAINER, I. The impact of the subtropical South Atlantic SST on South American precipitation. Annales Geophysicae, v. 26, p. 3457-3476, 2008.

UNITED STATES. Bureau of Safety and Environmental Enforcement. Occurrence Rates for Offshore Oil Spills. 2016. Available at: https://www.bsee.gov/sites/bsee.gov/files/osrroil-spill-response-research/1086aa.pdf Access: 2020.

VILCA, F. Z.; ROSSI, S.; OLINDA, R. A.; SÁNCHEZ-SARMIENTO, A. Z.; PRIOSTE, F.; MATUSHIMA, E. R.; TORNISIELO, V. L. Concentrations of polycyclic aromatic hydrocarbons in liver samples of juvenile green sea turtles from Brazil: Can these compounds play a role in the development of fibropapillomatosis? Marine Pollution Bulletin, v. 130, p. 215-222, 2018. https://dx.doi.org/10.1016/j.marpolbul.2018.03.021

WAGENER, A. L. R.; MENICONI, M. F.; HAMACHER, C.; FARIAS, C. O.; SILVA, G. C.; GABARDO, T. I.; SCOFIELD, A. L. Hydrocarbons in sediments of a chronically contaminated bay: The challenge of source assignment. Marine Pollution Bulletin, v. 64, n. 2, p. 284-294, 2012. https://dx.doi.org/10.1016/j.marpolbul.2011.11.018

YIN, L.; ZHANG, M.; ZHANG, Y.; QIAO, F. The long-term prediction of the oil-contaminated water from the Sanchi collision in the East China Sea. Acta Oceanologia Sinica, v. 37, n. 3, p. 69-72, 2018. https://dx.doi.org/10.1007/s13131-018-1193-5

ZACHARIAS, D. C. Development of STFM (Spill, Transport and Fate Model): Lagrangian Computation Model of Transport and Weathering of Oil Slick. 2017. Doctoral Thesis - Institute of Astronomy, Geophysics and Atmospheric Sciences, University of São Paulo, São Paulo, 2017. 